\title{
LE CLÈZIO, J.M.G. O AFRICANO. São Paulo: Cosac Naify, 2007.
}

Resenhado por: Luciana Carvalho ${ }^{1}$

O Africano, de J.M.G. Le Clézio, prêmio Nobel de literatura 2008, é indubitavelmente um livro impregnado de afetividade, que contém uma força vital singular, capaz de nos arrastar em um turbilhão de sensações mágicas ao longo de cento e vinte e duas páginas prenhes de significados em cada signo que nos salta aos olhos, como estrelas flamejantes a traspassarem a obscuridade dos significantes.

Narrado em primeira pessoa, trata-se do itinerário de autogeração do autor, o qual permite ao leitor, pelos rastros deixados por essa memória viva, rica em sabedoria, experienciar uma comoção estética que nos dá o ensejo de também voltar atrás, de também recomeçar. Como a Fênix, o narrador-adulto se reinventa através do retorno às origens, quando o menino que ainda o habita não conseguia enxergar para além do capinzal amarelado que se estendia a partir da cerca de mato do quintal da sua casa até o rio Aiya, cujas planícies, de ambos os lados, Ihe pareciam ilimitadas. É ali, na África Ocidental, nos confins da Nigéria, mais especificamente em Ogoja, pequeno vilarejo, constituído unicamente de iorubas e ibos, que esse menino, na época com oito anos, levado pela mãe e na companhia do irmão, vai conhecer um pai, como ele mesmo diz, amargo e autoritário, de quem havia sido separado, desde o nascimento, pelas contingências da guerra. Um pai de quem não guardava nenhuma lembrança, e por quem não nutria nenhum tipo de sentimento a não ser temor.

A viagem iniciática desse personagem-narrador começa, pois, justamente aí nesse minúsculo ponto perdido no mapa-múndi, onde, correndo descalço pelas savanas, sob um céu imenso, aprende o verdadeiro sentido da liberdade. Nesse mundo abafado e selvagem, povoado de insetos, marcado por cicatrizes nos corpos gastos e

\footnotetext{
${ }^{1}$ Doutora em Literatura pela Universidade Federal do Rio Grande do Sul
}

Organon, Porto Alegre, nº 47, julho-dezembro, 2009, p.231 - 234 
desnudos, mundo de tempestades violentas e de redemoinhos de poeira levantando da terra seca e vermelha, a linguagem, pois, torna possível, num absoluto literário, o testemunho dessa passagem do menino mimado, no apartamento em Nice, durante o confinamento de cinco anos de guerra, ao menino-embrião do adulto que irá se transformar, recuperando para si um rosto que lhe era estranhamente familiar.

A figura do pai é poderosa, tão poderosa quanto a África, para o narrador que, agora, distante no tempo, busca reinterpretar, através de arquivos pessoais e de objetos da vida cotidiana, uma memória que não é somente sua, mas do homem que Ihe deu as feições do corpo e do espírito, fonte de seus sentimentos e de suas determinações, mesmo que o destino os tenha mantido à distância. A ancestralidade evoca desde sempre uma espécie de elo entre eles. E é nesse momento que a narrativa toma outro rumo. O protagonista passa a ser esse "africano de alma", essa figura inicialmente desconhecida, símbolo de austeridade, que, aos poucos, vai se metamorfoseando, ao olhar do filho, num ser humano valoroso, com quem ele então se identifica.

O pai é inglês, nascido nas ilhas Maurício. Concluído o curso de Medicina, em Londres, passa dois anos como médico itinerante nos rios da Guiana Inglesa, e, em 1928, chega à África, onde vai viver durante mais de vinte anos, cuidando da saúde milhares de pessoas, até sua aposentadoria (na década de 50), quando então retorna com a família para França, após tanto tempo de afastamento, exilado daqueles que mais amava. A solidão a que fora submetido faz com que o silêncio se torne a herança de sua resistência, de sua obstinação.

Como se percebe, temos uma narrativa que flui, como um rio, em dimensões paralelas que acabam por se tocar no final, desaguando, límpidas, em um oceano profundo, a qual é justamente esse encontro (ou reencontro) do narrador com a sua própria história. Do mesmo modo, temos uma história segunda (nem por isso menos fundamental), que se atravessa e se embrenha, a todo instante, nessa narrativa absolutamente humana e intemporal: a História da colonização africana, paradoxalmente tão real e tão absurda que expõe a violência (como fratura) até o osso, provocando-nos uma reflexão pungente sobre o sentido da existência.

As imagens são tantas (e aqui não me refiro apenas às fotografias que, de alguma maneira, mostram um pouco da intimidade dessa família nuclear da narrativa), 
mas às metáforas que vão tecendo o relato, fio após fio, fundadoras de todo o imaginário que fabricamos após a leitura deste livro fecundo em conotações, capaz, repito, de nos prender no olho do furacão. A primeira (e talvez a mais próxima do conteúdo do coração e da consciência desse homem que se especula) é a do espelho, objeto revelador da verdade, o qual o narrador-protagonista confessa ter evitado durante anos de sua vida, provavelmente para manter a ilusão de um passado confessadamente inventado, de uma identidade que não era a sua.

É a partir, portanto, dessa imagem que o enredo se desenrola. E é a essa imagem que o narrador, já adulto, retorna para falar da "substância etérea que circula entre as divisórias do real", a qual separa o seu mundo de hoje do seu mundo de ontem, na África, onde se sentia abrigado, como no interior de uma gruta (lugar que figura nos mitos de origem, de renascimento e de iniciação).

De fato, essa simbologia da gruta se liga a outras de igual vetor, tais como a da casa e a da mãe. Aquela remete ao ser interior; essa, a origem de todos os instintos; ambas, entretanto, evocam a subjetividade em luta com os problemas de sua diferenciação. Uma leva a outra. Tanto a choupana em Ogoja, que remete à melhor parte da sua infância, quanto o sobradinho de madeira, em Forestry House, em que seu pai e sua mãe viveram os primeiros anos de casamento, representam, para o narrador, "um tesouro vivo em seu íntimo, que não pode ser extirpado". Ou seja, a sua identificação, o seu processo de interiorização psicológica, segundo o qual se tornou ele mesmo, conseguindo chegar à maturidade.

A África é, portanto, enquanto arquétipo do útero e do seio materno, a mãe que o concebeu e nutriu. Com sua negritude, indica a fase inicial dessa evolução progressiva. É no continente africano que experimenta, como nunca, a sensação de felicidade, de "fazer parte de uma célula", uma vez que é ali, nesse cosmo vivo, que encontra, pois, as suas raízes, a sua essência. Em oposição à Europa fria, atormentada pela guerra, monstro infernal, simboliza o calor como potência que lhe permite "um nascer do caos primordial" (isto é, o calor o faz amadurecer, biológica e espiritualmente).

Nesse sentido, antes de renascer para a verdade, esse menino, já foi dito, teve que enfrentar outro mundo, muito mais violento e assustador, a despeito de toda a violência física que presenciou durante a sua estadia em Ogoja: o mundo das falsas 
aparências e das ilusões (mundo dos nevoeiros), em que as pessoas transitavam perturbadas e indistintas, angustiadas pelo terror de uma guerra de conseqüências nefastas. Esse mundo, como cinza extinta, adquire na narrativa um valor apenas residual.

Todavia, na contramão do discurso, tal resíduo reaparece como "silêncio interminável", não só do pai, um sobrevivente dessa calamidade universal, mas de todos aqueles corpos sem rosto que se movimentavam, livres, naquele cenário selvagem que o narrador vai pintando, em pinceladas fortes e expressivas, no afã de recapturar, no seu estado puro, um tempo, por assim dizer, mítico (e o faz com sentimentos, muito mais do que com palavras).

Assim, a África, essa "violência das sensações, dos apetites e das estações", é o paraíso reencontrado. Todo homem nasce da união de um homem (Adão) com uma mulher (Eva). Essa é a chave do mito do Éden, que está na gênese da sociedade ocidental. Pois, em O Africano, o autor/narrador prefacia: "todo ser humano é um resultado de pai e mãe", numa associação (in) direta com o relato bíblico. Por mais que a relação entre pai e filho tenha sido comprometida por uma desgraça (a guerra, serpente que se converteu em demônio, inimigo implacável e poderoso), após longos anos de sofrimento, a África aparece como resgate. Não a África do presente da narrativa, vista por um menino de oito anos, recém abrindo os olhos para a realidade, e sim a das lembranças que se transformaram em certezas neste "pequeno livro de memórias".

Aqui, como Adão, o pai é um expatriado, um estrangeiro, um hóspede de passagem, mas, ao contrário do personagem bíblico, ele não é expulso do paraíso. A África "irá tornar-se para ele, por força e por necessidade, sua terra verdadeira", seu paraíso perdido, "Ionge da zona civilizada" (Europa). Seu caminho é, portanto, inverso. E é esse pai, já no fim da vida, que o filho vai assimilar para si como legado. Um pai que, junto com a mãe, quando ainda eram jovens e felizes, se aventurou, como num sonho, livre de pecados, por caminhos até então insondáveis.

Por tudo isso, o romance de Le Clézio, ainda que comporte "histórias de família", valendo sua leitura pelo simples fato de serem histórias que sabem mesclar realismo e lirismo, conseguindo abandonar a imagística exótica das lendas, sem com isso afetar a beleza idílica do relato, é antes a expressão de uma crise profunda, a 
dramatização, no imaginário, da violência da guerra, que impõe pelo medo, que ensina o ódio e a estupidez, que manifesta implacavelmente o repugnante egoísmo dos homens, engajando-os numa luta em que o que está em jogo é a morte.

Quando o narrador-menino, junto com o irmão, destrói por nada (simplesmente pelo prazer de destruir) a cidade dos cupins, essa cena pode ser entendida como representação metafórica da impunidade colonial. Nesse momento, feito mosquitos, símbolo da agressividade, os quais procuram obstinadamente violar a vida íntima de sua vítima e se alimentar de seu sangue, eles se lançam, raivosos, num território que não é o seu, impondo-se pela força, numa destruição lenta e impiedosa.

No entanto, esse "massacre de covardes", em O Africano, vem à tona enquanto furor que, mais do que ser esquecido, apagado da memória, deve servir como ilustração dos componentes psicológicos de uma tragédia que ultrapassa todas as circunstâncias próprias a uma época e a um país, adquirindo um valor universal.

Desse modo, nas imagens e nas palavras, com profundidade e envergadura, exprimem-se, nesse livro, todas as emoções, ao mesmo tempo simples e complexas, dos seres humanos: felicidade e infelicidade; alegria e tristeza; nostalgia da inocência e angústia da culpabilidade, enfim... Estabelece-se aí, pois, uma dialética: um canto de amor num campo de batalha ou um grito de guerra num campo de amor.

Organon, Porto Alegre, n 47, julho-dezembro, 2009, p.231 - 234 